\title{
〈マイクロ流路を用いたエンドトキシン凝固反応の計測〉
}

$<$ Measurement of endotoxin-clotting reaction with microchannel $>$

\author{
$\langle 0$ 小谷 紘 (広島大学) 〉〈舟橋 久景 (広島大学)〉〈黒田 章夫 (広島大学) 〉〈正 三宅 亮 (東京大学) 〉
}

\begin{abstract}
<Hiroshi Kodani, Hiroshima University, 1-4-1 Kagamiyama Higashi-Hiroshima-shi Hiroshima-ken 739-8527 JAPAN> <Hisafuna, Funabashi University, 1-4-1 Kagamiyama Higashi-Hiroshima-shi Hiroshima-ken 739-8527 JAPAN> <Akio, kuroda University, 1-4-1 Kagamiyama Higashi-Hiroshima-shi Hiroshima-ken 739-8527 JAPAN> <Miyake ryo, Tokyo University, 7-3-1 Hongo Bunkyoku Tokyoto 113-8654 JAPAN>

$<$ As a result of the experiments using the endotoxin test kit commercially available, it was found that the coagulation change appears more quickly endotoxin concentration is higher. So, a method for measurement of the coagulation reaction to detect the difference in flow velocity of the micro flow channel due to coagulation was proposed. The specification required for endotoxin test analysis chip design was given experimentally.>
\end{abstract}

Key Words: <endotoxin, microchannel, coagulation >

1.はじめに

凝固活性検査（血液凝固、エンドトキシン検査）の中でも、 エンドトキシン㭘査は敗血症の早期発見や、透析液や輸血時 の污染管理の観点から近年急激にその重要性が訴求されつ つある。エンドトキシンとは強力な毒素であり、環境中に広 く常在している細菌に由来している。また代表的な発熱性物 質（体内において体温上昇作用を引き起こす物質の総称）で あり、エンドトキシンが低濃度（10 pg/ml オーダー）でも血 液中に入ると発熱やショックなどの作用が起こり、致死の危 険性がある。そのため医療現場では簡便、高頻度かつ定量的 な計測法が望まれている。そこで、簡便な分析チップの開発 を目的とした。

エンドトキシンの測定方法には凝固測定法、比濁時間分析 法、合成基質法の 3 つがある。この中でも比較的簡素な系で 測定ができる方法として凝固測定法がある。エンドトキシン がカブトガニの血清抽出物（リムルス試薬）と反応すること で凝固することを利用したものであるが、現状では陰性・陽 性の検出キットが市販されているのに留まる。そこで、この 凝固反応変化を何らかの方法により測定することで、エンド トキシン濃度の定量測定ができないかと考えた。即ちエンド トキシン濃度が高いと凝固する時間が短くなると仮定し、一 定時間後の反忘液の物理特性変化を㭘出部で計測する。

\section{2. エンドトキシン濃度と凝固反応速さ}

市販のエンドトキシン検查キット（和光純薬製）を用い、 時間経過による凝固変化の観測を行った。リムルス試薬とエ ンドトキシン試料（200 $\mu \mathrm{L} ）$ を混合後、 $37{ }^{\circ} \mathrm{C}$ に保ち、凝固 状態の時間変化を目視観察・記録した。エンドトキシン濃度 を変更した場合の凝固反忘の時間変化を調べた。表 1 に結果 を示す。

表 1 より、エンドトキシン濃度が高くなると凝固反応が早 くなること確認した。この実験結果より、エンドトキシン濃 度によって凝固試料の粘度に変化が生じるのではないかと 考えた。そこで、次に凝固反応試料を実際にマイクロ流路内 に流して、その流動性を評価することとした。
Table 1. Change of cagulation depending on time

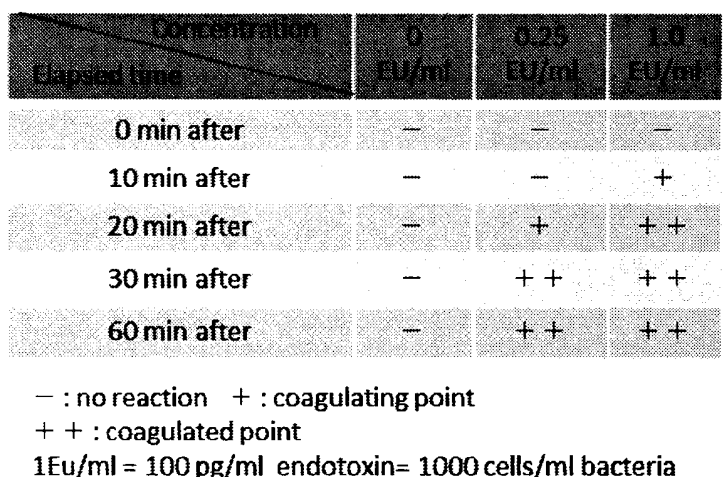

\section{3. 凝固試料の流動性評価実験}

流動性の評価方法として、図 1 に示す細管（内径 $0.5 \mathrm{~mm}$ ) の一端から吸引ポンプにて、もう一端から凝固試料を吸引寸 ることにより、細管中の一定区間 $(800 \mathrm{~mm})$ を流れる時間 $(\Delta \mathrm{T}$ とする)の濃度依存性を評価した。

測定手順として、(i )細管の一端を試料内に入れる。(ii)試 料が一定量のところまできたら、細管の一端を試料から離す。 (iii) 細管中の試料が測定区間の始点に来たら、ストップ ウォッチを ONにする $\left(\mathrm{t}=\mathrm{t}_{1}\right)$ 。(iv)細管中の試料が測定区 間の終点に来たら、ストップウォッチを $\mathrm{OFF}$ にする $\left(\mathrm{t}{ }_{2}\right)$ 。 ここで、細管の一端から試料が一定量のところまで来た時に、 細管の一端を試料から離すことで、細管中の液量を一定とし た。その理由は、細管中の液体の圧力損失一定にすることで、 測定区間 L の始点と終点での速度が同じとなり、平均速度 v を容易に求めるためである。その結果をグラフにしたものを 図 2 に示す。

エンドトキシン検査キットと比べ短時間 $(5 \sim 10$ 分 $)$ で凝固有 無、及び濃度推定の可能性があることがこの寒験により明ら かになった。この特性を用い、細管を用いたエンドトキシン 検査用マイクロ流路分析チップの設計を行うこととした。 


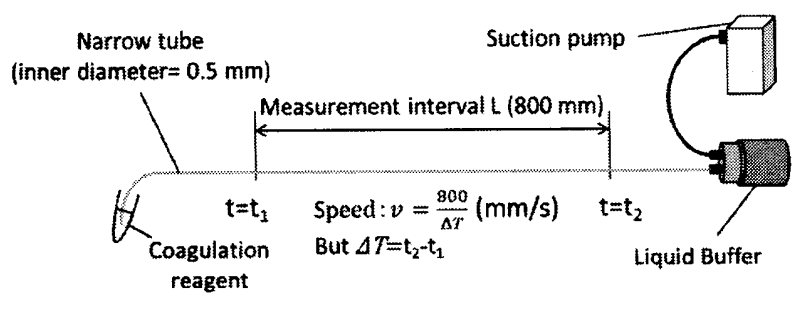

Fig. 1 Liquidity evaluation experimental setup of coagulation sample

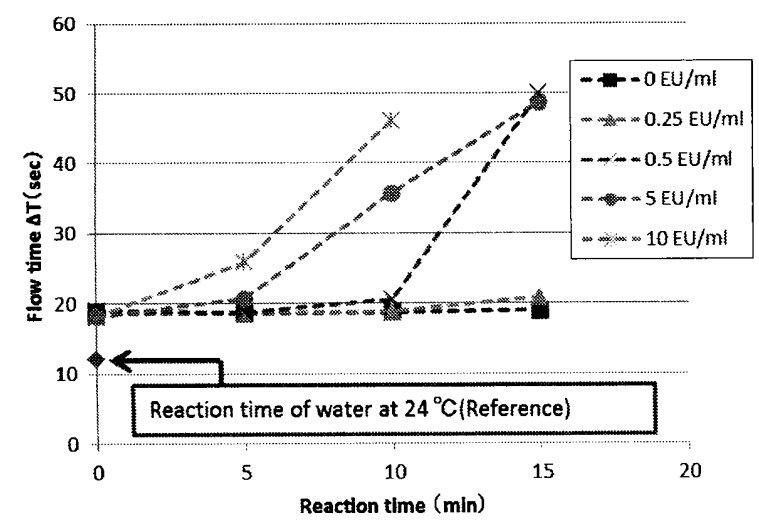

Fig. 2 Experimental result

\section{4. 分析チップ用流路の設計}

図 3 にマイクロ流路分析チップの構成図を示す。検査部 $\mathrm{L}_{\mathrm{d}}$ の長さはチップサイズの制約から $10 \mathrm{~mm}$ とした。またサン プル投入口から試料を投入後、液の先端部が検査部に至り、 通過する時間として、5 秒を想定した。すなわち検査部 $\mathrm{L}_{\mathrm{d}}$ を通過する際の平均流速 $\mathrm{V}_{\mathrm{m}}$ は $2.0 \mathrm{~mm} / \mathrm{s} \quad(=10 \mathrm{~mm} / 5$ 秒）とな る。また流路の断面サイズとして Si の微細加工を利用する ため $50 \times 20 \mu \mathrm{m}^{2}$ とした。流す試料の計測時点での流動物性 としては図 2 の実験結果に示すように、もっとも流動性の低 い濃度 $10 \mathrm{EU} の 10$ 分経過時点の粘性を参考にすることにし た。ちなみに図 2 の各実験結果を基にそれぞれの濃度・時間 における動粘度を推定したグラフを図 4 に示す。このグラフ から濃度 $10 \mathrm{EU} の 10$ 分経過の試料に打ける推定動粘度 $v$ は、 $3.8 \mathrm{~mm} 2 / \mathrm{s}$ である。以上の条件のもと、式（1）を用いて、入 口長さ L を求めたところ、23 mm が得られた。以上の検討結 果をまとめたチップ仕様を表 2 に示す。

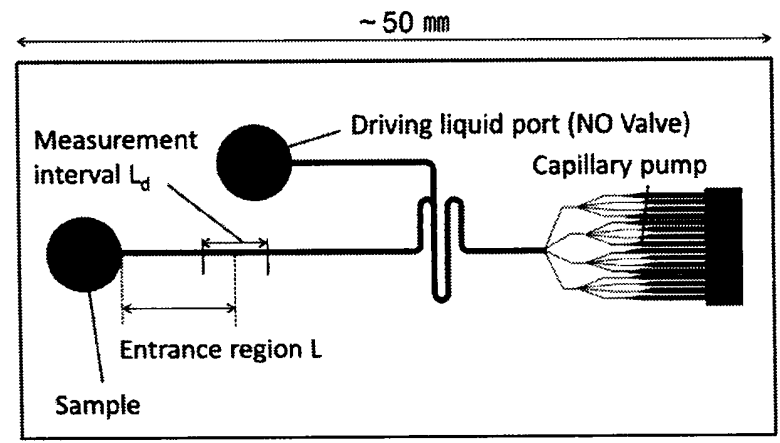

Fig. 3 Configuration of micro-channel chip

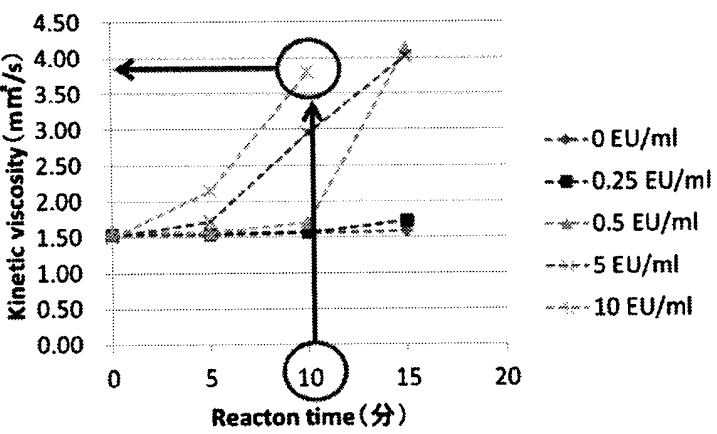

Fig. 4 Estimation of kinematic viscosity from the liquidity experimental result

$L=\frac{2 g d_{c}^{2} h_{c}}{64 v v_{p i 1}}, d_{c} \cong \frac{4 a \times b}{2(a+b)}$

$d_{c}$ : Hydraulic diameter in the entrance region of the chip $v_{m}$ : Set flow rate at the measurement interval $(\mathrm{mm} / \mathrm{s})$ $h_{\mathrm{c}}$ : Suction pressure hydrocephalus of the capillary pump (mmAq)

g: Acceleration of gravity $\left(\mathrm{mm} / \mathrm{s}^{2}\right)$

$v$ : Kinetic viscosity $\left(\mathrm{mm}^{2} / \mathrm{s}\right)$

Table 2. Specification of micro-channel chip

\begin{tabular}{|l|c|}
\hline Tube width $\mathrm{a}(\mu \mathrm{m})$ & 50 \\
\hline Tube depth $\mathrm{b}(\mu \mathrm{m})$ & 20 \\
\hline Set up Flow rate $\mathrm{v}_{\mathrm{m}}(\mathrm{mm} / \mathrm{s})$ & 2.0 \\
\hline Measurement interval $\mathrm{L}_{d}(\mathrm{~mm})$ & 10 \\
\hline Entrance region $\mathrm{L}(\mathrm{mm})$ & 23 \\
\hline
\end{tabular}

\section{5. まとめと今後の予定}

凝固反忘の測定方法として、凝固に伴うマイクロ流路内で の流動速度の差を検出する方法を提案した。エンドトキシン 検査用マイクロ流路チップの設計に必要なパラメータをマ イクロ流路での凝固試料の流動時間を測定することで求め た。今後の予定として、求めた仕様に基づきエンドトキシン 検查用マイクロ流路分析チップを試作し、動作評価を実施す る。

\section{引用文献}

[1] S. Okabe, K. Sakamoto, Y. Murakami, T. Ishikawa, R. Miyake, " MICR0-LIQUID HANDLING ON PAPER ANALYSIS CHIP TRIGGERED BY INK-JET DROPLET" , Proceedings of 16th Int. Conference on Transducers' 11, 318-321 (2011)

[2] S. Okabe, K. Sakamoto, Y. Murakami, T. Ishikawa, R. Mi yake, " PUMPS, NO-VALVES, NC-VALVES ON PAPER ANALYSIS CHIP" Proceedings of 25th Int. Conference on Micro Electro Mechanical Systems (MEMS 2012), 1101-1104 (2012) 